\title{
Pengaruh Diet Tinggi Minyak Sawit Terhadap Sel Hepatosit Tikus
}

\author{
Susila Sastri, Husnil Kadri
}

Abstrak

Pendahuluan: Minyak sawit yang dikonsumsi berlebihan tetapi tidak diimbangi pembakaran energi (oksidasi asam lemak) dapat menyebabkan penimbunan lemak di hepar. Oksidasi asam lemak diatur oleh faktor transkripsi peroxisome proliferator-activated receptor- $\alpha$ (PPAR- $\alpha$ ) di mitokondria dan peroksisom sel hepar. Gangguan sensitifitas PPAR- $\alpha$ menyebabkan penurunan oksidasi asam lemak sehingga berakibat pada terbentuknya vakuol lemak yang dapat berujung terjadinya perlemakan hepar. Penelitian ini bertujuan untuk menentukan bagaimana pengaruh diet tinggi minyak sawit terhadap jumlah vakuol lemak yang terbentuk pada sel hepatosit tikus. Metode: Desain penelitian ini adalah post-test experimental yang dilaksanakan di laboratorium. Tikus putih galur Wistar jantan sebanyak 15 ekor dengan berat badan antara 200-250 gram dibagi 3 kelompok yang terdiri dari; Kelompok kontrol negatif diberi diet standar 6-7gr/hari, Kelompok kontrol positif diberi diet standar ad libitum, Kelompok diet tinggi minyak sawit (diet standar + MS 50\%) diberikan ad libitum. Setelah 4 minggu, semua tikus dibantai untuk diambil heparnya. Hepar tersebut diawetkan dalam larutan formalin, kemudian diwarnai dengan Hematoksilin Eosin (HE) pada kaca objek. Sediaan ini selanjutnya dilihat dengan mikroskop pada pembesaran 400X. Perlemakan hepar ditentukan berdasarkan jumlah vakuol lemak intrasel yang dihitung per 100 sel. Hasil: Pada Kelompok kontrol negatif hanya ada satu vakuol lemak per100 sel, tetapi pada kelompok lain terdapat perbedaan yang bermakna $(p<0,05)$ rerata jumlah vakuol lemak antara kelompok diet tinggi minyak sawit $(72 \pm 14,83)$ dan diet standar ad libitum $(8 \pm 4,47)$. Kesimpulan: Diet tinggi minyak sawit pada tikus terbukti dapat menyebabkan perlemakan hepar.

Kata kunci: minyak sawit, PPARa, vakuol lemak, perlemakan hepar

\section{Abstract}

Introduction: Excess palm oil consumption but reduced energy burning (fatty acid oxidation) appear to be the cause of lipid storage in the liver. Fatty acid oxidation system in the liver is controlled by peroxisome proliferator-activated receptor- $\alpha$ (PPAR- $\alpha$ ) regulated mitochondrial and peroxisomal. Ineffective PPAR- $\alpha$ sensing can lead to reduced oxidation resulting accumulation of fat vacuole that can manifests as hepatic steatosis. The objective of this studi was to determine the effect of high palm oil diet on fat vacuole in liver parenchymal cells of rat. Method: This was a post test experiment design in laboratorium. Fifteen male wistar rats with 200-250 gram weight which divided into three group of five rats each, i.e. negative control (standard diet 6-7gr/day), positive control (standard diet ad libitum), and high palm oil group (standard diet with $50 \%$ palm oil ad libitum). After 4 weeks, all rats were slaughtered to take the livers, then the liver were preserved in formaldehyde for stained with haematoxylin eosin (HE) on the glass object. The preparation was seen with a microscope at $400 X$ magnification. Hepatic steatosis is determined by the amount of intracellular fat vacuole calculated per 100 cells. Results: In the negative control group there was only a fat vacuole per 100 cells, but on the other hand there is a significant difference $(p<0.05)$ between high palm oil diet group $(72+14.83)$ and standard diet ad libitum $(8+4$, 47). Conclusion: The high palm oil diet in rats shown to cause hepatic steatosis.

Keywords: palm oil, PPAR- $\alpha$, fat vacuole, hepatic steatosis.

Affiliasi penulis : Bagian Biokimia Fakultas Kedokteran Universitas Andalas Padang Korespondensi : husnilbiokimia@yahoo.com Telp: 075121233

\section{Pendahuluan}

Minyak goreng yang sering digunakan masyarakat adalah minyak sawit (MS) jenis palm oil. Minyak sawit terutama mengandung unsaturated fatty acid (USFA) 50\% dan saturated fatty acid (SFA) palmitat $44 \%{ }^{1}$

SFA dalam sel adiposit meningkatkan kerja reseptor pada nukleus. Reseptor yang dipengaruhi adalah PPAR- $\alpha$ pada hepatosit dan PPAR- $\gamma$ pada jaringan adiposa. ${ }^{2}$ Peningkatan SFA dalam sel akan memicu reseptor diatas untuk mengaktifkan atau membentuk beberapa enzim yang dibutuhkan pada lipogenesis dan oksidasi asam lemak. Peningkatan asam lemak bebas dalam darah pada awalnya dapat kembali menjadi kadar normal, melalui lipogenesis pada sel adiposit dan oksidasi asam lemak pada hepatosit. Tetapi bila jumlah konsumsi SFA berlebihan dapat menyebabkan pembentukan trigliserida (TG) yang berlebihan pula dan mengganggu fungsi adiposit dan akhirnya meninggikan TG dan asam lemak darah. $^{3}$

Patogenesis perlemakan hepar (hepatic steatosis) pada alcoholic fatty liver disease (AFLD) maupun non alcoholic fatty liver disease (NAFLD) ditentukan oleh banyak faktor. NAFLD dapat disebabkan oleh asupan berlebihan glukosa dan atau 
asam lemak yang tidak diimbangi oleh peningkatan pembakaran energi menyebabkan factor transkripsi peroxisome proliferator-activated receptor- $\alpha$ (PPARa)di mitokondria dan peroksisom hepatosit menjadi kurang sensitif untuk mengoksidasi asam lemak, akibatnyaPPARy meningkatkan sintesis trigliserida dari asam lemak yang tidak teroksidasi tersebut. Penurunan fungsi PPAR- $\alpha$ dan peningkatan PPARy akan memicu terbentuknya vakuol-vakuol lemak di sitoplasma yang bila dalam jumlah berlebihan dapat mengakibatkan perlemakan hepar (hepatic steatosis). ${ }^{4}$

Diet tinggi minyak sawit akan meningkatkan profil lemak darah karena kebutuhan tubuh terhadap lemak yang dianjurkan hanya (30\%) dari kebutuhan kalori, sedangkan batasan untuk PUFA hanya 3-4 \% dari kebutuhan energi. Konsumsi minyak sawit berlebihan dari kebutuhan tubuh dapat saja terjadi karena kebiasaan makan atau anggapan bahwa lemak tak jenuh dapat menurunkan kolesterol. ${ }^{5}$

Penelitian ini bertujuan untuk menentukan bagaimana pengaruh diet tinggi minyak sawit terhadap jumlah vakuol lemak yang terbentuk pada sel hepatosit.

\section{Metode}

Desain penelitian ini adalah post-test experimental yang dilaksanakan di laboratorium. Pemeliharaan dan perlakuan binatang percobaan dilaksanakan pada laboratorium binatang Farmasi Universitas Andalas (Unand). Profil lemak darah diperiksa dengan spektrofotometer di laboratorium Biokimia Fakultas Kedokteran Unand dan pemeriksaan jaringan hepar dilaksanakan pada laboratorium Patologi Anatomi di Fakultas Kedokteran Unand. Populasi penelitian adalah 15 ekor tikus galur Wistar jantan berumur \pm 2 bulan dengan berat badan 200-250 gr.

Diet standar tikus mengandung karbohidrat $76,4 \%$, lemak $4,6 \%$, dan protein $19 \%$, sedangkan minyak sawit yang digunakan adalah dengan merek dagang tertentu.

Binatang percobaan sebelum diperlakukan dibiarkan dalam kandang selama satu minggu untuk adaptasi. Kemudian;

- Kelompok KN sebagai kontrol negatif diberi diet standar 6-7gr/hari sesuai kebutuhan selama 4 minggu

- Kelompok KP sebagai kontrol positif diberi diet standar ad libitum selama 4 minggu

- Kelompok DMS diberi diet tinggi minyak sawit: diet standar + MS 50\% diberikan ad libitum selama 4 minggu sebagai perlakuan

Jaringan hepar diawetkan dalam larutan formalin, kemudian diwarnai dengan Hematoksilin Eosin (HE) pada kaca objek. Sediaan ini selanjutnya dilihat dengan mikroskop pada pembesaran 400X.

Data profil lemak darah tikus disajikan dalam bentuk tabel. Uji statistik menggunakan perangkat lunak SPSS 15.0. Perbedaan rerata antar kelompok ditentukan dengan uji Anova setelah dilakukan uji normalitas dan varian data.

\section{Hasil}

Setelah pemberian 3 macam perlakuan diet terhadap subjek selama 4 minggu, maka didapatkan nilai rerata profil lemak darah seperti pada Tabel.1 dibawah ini.

Tabel.1 Perbedaan Rerata Profil Lemak Antar Kelompok

\begin{tabular}{|c|c|c|c|c|}
\hline No. & Kadar & $\begin{array}{c}\text { Diet } \\
\text { Standar } \\
(\mathrm{n}=5)\end{array}$ & $\begin{array}{c}\text { Diet } \\
\text { Standar } \\
\text { ad libitum } \\
(\mathrm{n}=5)\end{array}$ & $\begin{array}{c}\text { Diet } \\
\text { Minyak } \\
\text { Sawit } \\
(n=5) \\
\end{array}$ \\
\hline 1 & $\begin{array}{l}\text { Kolesterol } \\
(\mathrm{mg} / \mathrm{dl})\end{array}$ & $\begin{array}{c}68.80 \pm \\
9.58\end{array}$ & $\begin{array}{c}60.20 \pm \\
6.87\end{array}$ & $\begin{array}{c}54.80 \pm \\
8.29\end{array}$ \\
\hline 2 & $\begin{array}{l}\text { Trigliserida } \\
(\mathrm{mg} / \mathrm{dl})\end{array}$ & $\begin{array}{c}47.00 \pm \\
17.01\end{array}$ & $\begin{array}{c}93.00 \pm \\
18.92\end{array}$ & $\begin{array}{c}98.40 \pm \\
38.88\end{array}$ \\
\hline 3 & $\begin{array}{l}\mathrm{HDL} \\
(\mathrm{mg} / \mathrm{dl})\end{array}$ & $\begin{array}{c}45.99 \pm \\
9.81\end{array}$ & $\begin{array}{c}29.71 \pm \\
11.59\end{array}$ & $\begin{array}{c}21.57 \\
4.76\end{array}$ \\
\hline 4 & $\begin{array}{l}\text { Non HDL } \\
(\mathrm{mg} / \mathrm{dl})\end{array}$ & $\begin{array}{c}22.81 \pm \\
3.85\end{array}$ & $\begin{array}{c}30.49 \pm \\
6.38\end{array}$ & $\begin{array}{c}33.23 \pm \\
7.61\end{array}$ \\
\hline 5 & $\begin{array}{c}\text { Kolesterol/H } \\
\text { DL }\end{array}$ & $\begin{array}{c}1.52 \pm \\
0.15\end{array}$ & $\begin{array}{c}2.23 \pm \\
0.72\end{array}$ & $\begin{array}{c}2.61 \pm \\
0.55\end{array}$ \\
\hline
\end{tabular}

Nilai kadar $=$ Rerata \pm SD

Rerata kadar kolesterol dan HDL pada Diet tinggi minyak sawit adalah paling rendah daripada Diet standar dan Diet standar ad libitum, sedangkan rerata kadar profil lemak lain lebih tinggi pada Diet tinggi minyak sawit.

Syarat uji statistik parametrik dengan one way Anova ialah sebaran data harus normal dan varian data harus sama. Uji normalitas Shapiro-Wilk menunjukkan sebaran data variabel kadar Non HDL pada kelompok MS berbeda $(p<0,05)$, tetapi uji homogeneity of variance menunjukkan varian data yang sama $(p>0,05)$. Oleh karena itu, variabel kadar Non HDL tidak memenuhi syarat uji one way Anova.

Hasil uji one way Anova menunjukkan terdapat perbedaaan yang bermakna $(p<0,05)$ pada kadar trigliserida, HDL, dan kol/HDL sedangkan kadar kolesterol tidak berbeda $(p>0,05)$ pada ketiga kelompok.

Hasil analisis post-hoc memperlihatkan bahwa kadar semua profil lemak pada kelompok Diet tinggi minyak sawit tidak berbeda $(p>0,05)$ dengan Diet standar ad libitum. Perbedaan yang bermakna $(p<0,05)$ hanya terdapat antara Diet tinggi minyak sawit dengan Diet standar. Kadar trigliserida dan HDL berbeda bermakna $(p<0,05)$ terdapat antara Diet standar dengan Diet standar ad libitum.

Uji Wilcoxon Signed Ranks terhadap kadar nonHDL menunjukkan perbedaan bermakna $(p<0,05)$ adalah antara Diet standar dengan Diet standar ad libitum dan Diet standar dengan Diet tinggi minyak sawit.

Vakuol lemak intrasel pada perlemakan hepar (fat metamorphosis) yang dihitung per 100 sel pada ketiga kelompok dapat dilihat pada Gambar.1. 


\begin{tabular}{|c|c|c|}
\hline Kelompok & Deskripsi & Gambar \\
\hline $\begin{array}{l}\text { Kontrol Negatif } \\
\text { (Diet standar) }\end{array}$ & $\begin{array}{l}\text { Sel ukuran normal. } \\
\text { Udema (-). } \\
\text { Sinusoid jelas. } \\
\text { Vakuol lemak intrasel } 1 \text { sel per } 100 \text { sel. }\end{array}$ & \\
\hline $\begin{array}{l}\text { Kontrol Positif } \\
\text { (Diet standar ad } \\
\text { libitum) }\end{array}$ & $\begin{array}{l}\text { Sel ukuran normal. } \\
\text { Udema (-). } \\
\text { Sinusoid jelas. } \\
\text { Vakuol ukuran kecil s/d } 10 \mu \text {. } \\
\text { Vakuol lemak intrasel } 10 \text { sel per } 100 \text { sel. }\end{array}$ & \\
\hline $\begin{array}{l}\text { Perlakuan (Diet } \\
\text { tinggi minyak } \\
\text { sawit) }\end{array}$ & $\begin{array}{l}\text { Sel ukuran besar/sembab } \\
\text { Udema (-). } \\
\text { Sinusoid kabur. } \\
\text { Vakuol ukuran besar s/d } 30 \mu . \\
\text { Vakuol lemak intrasel } 80 \text { sel per } 100 \text { sel. }\end{array}$ & \\
\hline
\end{tabular}

Gambar.1. Perlemakan hepar tikus (ditampilkan hanya satu untuk tiap kelompok)

Pada Tabel.2 dibawah ini terlihat jelas perbedaan yang sangat menyolok terhadap jumlah vakuol lemak akibat Diet tinggi minyak sawit dibanding Diet standar dan Diet standar ad libitum. Terdapat perbedaan yang bermakna $(p<0,05)$ rerata jumlah vakuol lemak intrasel/100 sel antara kelompok Diet tinggi minyak sawit dan Diet standar ad libitum dengan nilai rerata $72 \pm 14,83$ pada Diet tinggi minyak sawit, sedangkan pada kelompok Diet standar ad libitum ialah $8 \pm 4,47$.

Tabel.2 Fat metamorphosis (Jumlah vakuol lemak

\begin{tabular}{cccc}
\multicolumn{4}{c}{ intrasel/100 sel) } \\
\hline No & $\begin{array}{c}\text { Diet } \\
\text { standa } \\
r\end{array}$ & $\begin{array}{c}\text { Diet standar } \\
\text { ad libitum }\end{array}$ & $\begin{array}{c}\text { Diet Minyak } \\
\text { Sawit }\end{array}$ \\
\hline 1 & 1 & 10 & 80 \\
2 & 1 & 5 & 50 \\
3 & 1 & 5 & 90 \\
4 & 1 & 5 & 70 \\
5 & - & 15 & 70 \\
\hline Rerata & 1 & $8 \pm 4,47$ & $72 \pm 14,83$ \\
\hline
\end{tabular}

Nilai kadar $=$ Rerata \pm SD

\section{Pembahasan}

Kadar kolesterol lebih rendah pada kelompok Diet tinggi minyak sawit dibanding Diet standar (Kontrol) juga didapatkan oleh Oluba.,et al, ${ }^{6}$ yang meneliti pengaruh minyak sawit 5\% terhadap kadar profil lemak serum darah tikus selama 6 minggu. Hal ini terjadi mungkin karena minyak sawit mengandung tokotrienol, isomer vitamin E. Penelitian lain menunjukkan bahwa tokotrienol mampu menghambat sintesis kolesterol in vivo. ${ }^{7}$

Pada penelitian Oluba, et al (2011) tersebut justru ditemukan kadar trigliserida dan nonHDL kol kebalikannya dari penelitian ini, yaitu pada Diet tinggi minyak sawit lebih rendah dibanding Kontrol, sedangkan kadar HDL lebih rendah tetapi tidak berbeda secara statistik. Perbedaan hasil ini mungkin disebabkan oleh persentase minyak sawit hanya $5 \%$.

Hasil berbeda juga didapatkan oleh peneliti yang menggunakan minyak sawit $12 \%$ terhadap tikus dengan Diet tinggi minyak sawit selama 8 minggu, dimana kadar kolesterol dan HDL lebih tinggi pada kelompok Diet tinggi minyak sawit, tetapi kadar trigliserida lebih rendah tidak berbeda bermakna. 
Perbedaan ini mungkin juga disebabkan oleh persentase minyak sawit yang digunakan. Oleh karena itu, Diet yang mengandung minyak sawit 50\% pada penelitian ini menyebabkan hipertrigliseridamia. Diet tinggi SFA meningkatkan kadar LDL, hal ini berkaitan dengan jumlah reseptor LDL, dimana diet tinggi SFA mengurangi jumlah reseptor LDL. Perubahan ini menyebabkan pengurangan fractional catabolic rate (FCR) LDL dan meningkatkan perubahan VLDL-remnant menjadi LDL. ${ }^{9}$ Penelitian ini tidak mengukur kadar LDL tetapi kadar non-HDL dapat menggambarkan kadar LDL secara tidak langsung, dimana kadar non-HDL didapatkan paling tinggi pada kelompok Diet tinggi minyak sawit. Overnutrition juga dapat menimbulkan problem pada endoplasmic reticulum (ER) yang mengakibatkan misfolding protein dan meningkatkan aktifitas inositol requiring kinase-1 (IREI) dan TNF-á sehingga terjadi peningkatan lipolisis dan berakibat peninggian lemak darah. $^{10}$

Gambaran perlemakan hepar yang sangat jelas pada kelompok Diet tinggi minyak sawit mungkin akibat asupan energy berlebihan yang berasal dari minyak sawit menyebabkan penurunan sensitifitas PPARa di hepar. Gangguan faktor transkripsi ini berakibat penurunan drastis oksidasi asam lemak dalam hepatosit, sehingga memicu PPARY meningkatkan pembentukkan adipogenesis/ perlemakan hepar. ${ }^{4}$

\section{Kesimpulan}

Kelompok Diet tinggi minyak sawit memperlihatkan rerata jumlah vakuol lemak intrasel paling banyak dibanding kelompok Diet standard an Diet standar ad libitum.

\section{Daftar Pustaka}

1. Roduit R, Morin J, Masse F, Segall L, Roche E, Newgard CB, Assimacopoulos JF, Prentki M. Glucose down-regulates the expression of the peroxisome proliferator-activated receptor-alpha gene in the pancreatic beta -Cell. J. Biol. Chem. 2000; 275: 35799-806.

2. Jump DB. Fatty acid regulation of gene transcription. Critical Reviews in Clinical Laboratory Sciences. 2004; 41: 41-78.

3. Slawik M, Vidal-Puig AJ. Lipotoxicity, overnutrition and energy metabolism in aging. Ageing Research Reviews. 2006; 5: 144-64.

4. Reddy JK, Rao MS. Lipid metabolism and liver inflammation. II Fatty liver disease and fatty acid oxidation. Am J Physiol Gastrointest Liver Physiol. 2006; 290: G852-G58.

5. Medina G, Virtue S, Lelliott C, Boiani R, Campbell M, Christodoulides C, Perrin C, Jimenez LM, Blount M, Dixon J, Zahn D, Thresher RR, Aparicio $\mathrm{S}$, Carlton $\mathrm{M}$, Colledge $\mathrm{WH}$, KettunenvMI, Seppanen-Laakso T, Sethi JK, O'rahilly S, Brindle K, Cinti S, Oresic M, Burcelin R, Vidal-Puig A. The link between nutritional status and insulin sensitivity is dependent on the adipocyte-specific peroxisome proliferator-activated receptor\{gamma\}2 isoform. Diabetes. 2005; 54: 1706-16.

6. Oluba OM, Eidangbe GO, Ojieh GC, Idonije BO. Palm and egusi melon oils lower serum and liver lipid profile and improve antioxidant activity in rats fed a high fat diet. Int. J. Med. Med. Sci. 2011; 3 (2): 47-51.

7. Mukherjee S, Mitra A. Health effects of palm oil. J Hum Ecol. 2009; 26(3): 197-203.

8. Karaji-Bani M, Montazeri F, Hashemi M. Effect of palm oil on serum lipid profiles in rats. Pak. J. Nutr. 2006; 5(3): 234-36.

9. Sessler AM, Ntambi JM. Polyunsaturated fatty acid regulation of gene expression. J. Nutr. 1998; 128: 923-26.

10. Borst SE, Conover CF. High-fat diet induces increased tissue expression of TNF- $\alpha$. Life Sciences. 2005; 77: 2156-165. 